\title{
Fate of COVID-19 Occurrences in Wastewater Systems: Emerging Detection and Treatment Technologies-A Review
}

\author{
Emmanuel Kweinor Tetteh *(D), Mark Opoku Amankwa ${ }^{\mathbb{D}}$, Edward Kwaku Armah \\ and Sudesh Rathilal (D)
}

Green Engineering and Sustainability Research Group, Department of Chemical Engineering, Faculty of Engineering and the Built Environment, Durban University of Technology, Steve Biko Campus Block S4 Level 1, Box 1334, Durban 4000, South Africa; amankwamark12@gmail.com (M.O.A.);

edwardkarmah@gmail.com (E.K.A.); rathilals@dut.ac.za (S.R.)

* Correspondence: ektetteh34@gmail.com; Tel.:+27-313-732-123

Received: 17 July 2020; Accepted: 16 September 2020; Published: 24 September 2020

check for updates

\begin{abstract}
The coronavirus (COVID-19) pandemic is currently posing a significant threat to the world's public health and social-economic growth. Despite the rigorous international lockdown and quarantine efforts, the rate of COVID-19 infectious cases remains exceptionally high. Notwithstanding, the end route of COVID-19, together with emerging contaminants' (antibiotics, pharmaceuticals, nanoplastics, pesticide, etc.) occurrence in wastewater treatment plants (WWTPs), poses a great challenge in wastewater settings. Therefore, this paper seeks to review an inter-disciplinary and technological approach as a roadmap for the water and wastewater settings to help fight COVID-19 and future waves of pandemics. This study explored wastewater-based epidemiology (WBE) potential for detecting SARS-CoV-2 and its metabolites in wastewater settings. Furthermore, the prospects of integrating innovative and robust technologies such as magnetic nanotechnology, advanced oxidation process, biosensors, and membrane bioreactors into the WWTPs to augment the risk of COVID-19's environmental impacts and improve water quality are discussed. In terms of the diagnostics of COVID-19, potential biosensors such as sample-answer chip-, paper- and nanomaterials-based biosensors are highlighted. In conclusion, sewage treatment systems, together with magnetic biosensor diagnostics and WBE, could be a possible way to keep a surveillance on the outbreak of COVID-19 in communities around the globe, thereby identifying hotspots and curbing the diagnostic costs of testing. Photocatalysis prospects are high to inactivate coronavirus, and therefore a focus on safe nanotechnology and bioengineering should be encouraged.
\end{abstract}

Keywords: advanced oxidation process; biosensors; magnetic nanoparticles; membrane bioreactor; wastewater-based epidemiology; ribonucleic Acid (RNA); SARS-CoV-2

\section{Introduction}

The severe and acute respiratory syndrome, coronavirus-2 (SARS-CoV-2), has been an etiological agent of COVID-19, which, according to the World Health Organization (WHO), is transmitted via respiratory droplets and contact routes [1,2]. According to Hart and Halden [3], SARS-COV-2 belongs to the coronvirinae subfamily made of positive-sense Ribonucleic Acid (RNA) viruses. Additionally, in human cells, this virus uses an angiotensin-converting enzyme (ACE2) as a receptor which is very high in the gastrointestinal system as a courier of ACE2 RNA. SARS-CoV-2 detections in human stools and urine of COVID-19 carriers have been reported to be potent [4]. Successive studies of finding the RNA of this virus in sewage systems raises notable concerns about COVID-19 faucal transmission and its pathogenic effects on sanitation and wastewater systems [3,4]. 
Municipal wastewater is typically observed as one of the main end routes of different types of emerging contaminants such as pharmaceuticals, endocrine disruptors, antibiotics, microplastics, pesticide and heavy metal residues associated with antimicrobial resistance (AMR) [5]. Sewage streams from the municipal system contain a large number of recalcitrant compounds which are usually excreted by humans and other activities. Notwithstanding, global hotspots for drug-infested countries where drug deals and usages are widespread are usually identified through the sewage systems [6]. Despite this, there are various measures surrounding the movement restriction of about $93 \%$ global population to monitor the COVID-19 spread and advisory interventions [3]. As such, extensive testing is required to understand the possible routes of the viral contagion, which is very expensive. Therefore, monitoring the spread of COVID-19 early stages in communities through the wastewater-based epidemiology (WBE) approach is useful [5,6]. Additionally, this could possibly provide rapid results for effective and urgent interventions in the fight against COVID-19.

Conversely, the COVID-19 pandemic has led to a paradigm shift of the world's societal and essential activities with a profound transformation of human life, which poses a global threat to socio-economic growth and development $[4,7]$. The risk and routine of waste collection and wastewater as an ecological response to address COVID-19 complications in water and wastewater settings has received little attention [8]. In response, this study introduces WBE to monitor the COVID-19 spread and its threats to public health, while analyzing the populated pooled wastewater to mitigate COVID-19 complications. In essence, over the past years, over 1500 pathogens have been discovered, with almost 40 of them emerging from communicable diseases with a major impact on communities [7,9]. These include severe and acute respiratory syndromes (SARS) (2002-2003), H1N1flu/swine flu (2009-2010), Ebola (2014-2016), Zika virus (2015-2016), and COVID-19 (2019-2020) [9]. As it stands, the search of vaccines for recurrence of communicable disease prevention and their treatment, in terms of COVID-19, seems far-reached. This has triggered an international ban at various airports and seaports on travel and social gathering, practicing quarantine protocols, school and church closures, and closures of non-essential industries [10]. According to the WHO report, as of 29 May 2020, over 5 million cases of Covid-19 cases were identified globally with 362,614 deaths and 2,596,004 people recovering [11].

Eventually, SARS-CoV-2 prevention interventions which consist of personal cleanliness, accurate sanitation, hand washing and sanitizing cannot be separated from a safe supply of water. Hence, water and wastewater industries amidst of addressing this global pandemic are going to revel in widespread economic impacts [12]. As a direct consequence of COVID-19 to the global economic system, countries along with South Africa and the United States of America are expected to suffer from huge financial losses of billions of dollars because of revenue discounts of their water utilities [13]. Upon this foundation and many extra anticipated in days to return, studies into figuring out and developing a strong era within the water and wastewater remedy settings to diminish the COVID-19 complications are useful.

Therefore, this paper seeks to discuss the cutting-edge state of the COVID-19 virus in terms of its fate, occurrence and removal from wastewater together with inter-disciplinary and technological procedures as a roadmap for water and wastewater sectors to sign up for the combat against COVID-19 and the future water crisis. The study in addition identifies magnetic nanotechnology, biosensors, and membrane bioreactors as progressive and robust techniques to enhance the purification of wastewater whilst at the same time minimizing the environmental impacts of COVID-19.

\section{Current State of COVID-19 in Wastewater}

The public health provides significant concentrations of SARS-CoV-2 arriving at WWTPs and the consequent discharge into the wider environment is alarming, even though no substantial studies have been done [14]. The spread of COVID-19 among human populaces might be identified too late, and the virus can only be detected when an enormous scale of human testing is accessible, or when clinical COVID-19 cases are accounted for by health experts, because the carriers are believed to exhibit no symptoms, or few non-specific symptoms [15]. Therefore, there have been investigations 
into the virus circulation among developed countries and emerging economies, including China, Netherlands, and Australia using stool samples [16]. The WHO (2020) reported that as of March 3, 2020, only two studies had been able to detect the viral RNA fragments of COVID-19 in the faucal matter of infected patients and that the transmission of the virus through faucal matter was low. In a study, COVID-19 viruses in 10 sampled stools in sewage plants in the Paris area in France were detected [17]. Scientists in the Netherlands also reported on a detected virus RNA in a WWTPs in Amersfoort, a city located 32 miles from southeast of Amsterdam [18]. SARS-COV-2 RNA in wastewater from 19 communities in Australia, a median range of 171 to 1090 infected people were identified in the communities [19]. In the same study, they further stated that the viral RNA copies were enumerated using the reverse transcriptase quantitative polymerase chain reaction (RT-qPCR), resulting in two positive detections within a six-day period from the WWTPs [20-24].

\subsection{Wastewater-Based Epidemiology (WBE) Monitoring of COVID-19}

Wastewater-based epidemiology (WBE) is a promising approach to better understand the occurrence of viruses in WWTP catchment population since the WW contains viruses excreted from symptomatic and asymptomatic individuals in a particular location under study [25]. Wastewater monitoring has a greater potential to provide early warning signs on how broadly SARS-CoV-2 is circulating in the community especially in the case of individuals showing mild symptoms or no symptoms at all $[23,24]$. Despite the applications of WBE in monitoring the outbreaks of enteric viruses such as norovirus, hepatitis virus, and poliovirus for public health interventions [25], there are still few studies documented on the concentration and detection of SARS-CoV-2 in wastewater settings [26]. Zhang et al. [27] reported binary RTqPCR data, while another recent study reported $\sim 250$ copies/mL SARSCoV-2 in wastewater in Massachusetts, USA. The authors of these studies further acknowledged that the estimated concentration was much greater ( $5 \%$ of all fecal samples in the catchment) than the confirmed cases $(0.026 \%)$. Several factors were proposed by the author on the discrepancies and considered their results conservatively. The estimated numbers of SARS-CoV-2 in the study by Ahmed et al. [4] were found to be 3-4 orders of magnitude lower than that reported by Hamidouche and Belmessabih [28].

Furthermore, Kozitsina et al. [29] assessed the stability of drug biomarkers in municipal WWTP as a major factor to influence the estimation of drug consumption using sewage epidemiology and their possible transformation in a sewer. The stability was conducted at 10 and $20^{\circ} \mathrm{C}$ in order to simulate typical winter and summer temperature conditions in the sewer system. It was found that among the 14 substances tested, the most unstable compounds were morphine-3- $\beta$-D glucuronide (MG), 6-acetyl morphine (6-AM), cocaine (COC) and 6-acetyl codeine (6-AC), while all other investigated compounds appeared to be relatively stable over a period of $72 \mathrm{~h}$. It was also reported in the same study that the transformation processes for all degradable compounds followed pseudo-first-order kinetics with significantly longer half-times during winter. The first detection of SARS-CoV-2 in untreated wastewater in Australia was confirmed by sequencing after shedding the virus in the stool of humans [4]. Their preliminary findings demonstrated the applicability of WBE for COVID-19 surveillance as a potential tool for public health monitoring at the community level. SARS-CoV-2 RNA was concentrated from a wastewater catchment in Australia, and viral RNA copies were numbered using the reverse transcriptase quantitative polymerase chain reaction (RT-qPCR), which resulted in two positive detections within a six-day period from the same WWTP [4]. Currently, it has been reported that RT-qPCR assays developed for clinical specimen testing are being used for SARS-CoV-2 RNA detection in wastewater samples. The Monte Carlo simulation predicted a median number of infections ranging from 171 to 1090 in the catchment basin in their study [4,7].

A major challenge encountered in some of the above studies has been the establishment of quantitative predictions from the viral RNA concentrations measured in the sewage to the actual number of cases in the community. For the application of WBE of SARS-CoV-2 infections, further systematic research possibly will be required in governing these aspects from effective sampling and preservation 
via data interpretation. This could be beneficial in remote communities and confined populations, which makes it very crucial. The development and/or identification of enveloped virus concentration methods and local data on the prevalence and concentration of SARS-CoV-2 in patients is, therefore, recommended [29]. Additionally, virus concentration should be considered as an essential factor with much attention to improving the sensitivity of SARS-CoV-2 detection in wastewater $[4,28]$. Idumah et al. [30] recounted that, contingent upon localized conditions, discovery in such a society's sewage and wastewater of one asymptomatic or symptomatic infected case per 100 to 2,000,000 non-contaminated individuals is hypothetically achievable. This is owing to some viable successes presently being accounted for from around the globe. Thus, with about 105,600 sewage plants that can be placed under surveillance, 2.1 billion people could be monitored globally [28-30]. The European Centre for Disease Prevention and Control (ECDPC) (2020) informs that as of 9 September 2020, they were able to report about 27,609,408 cases of COVID-19 with 898,087 deaths globally (Figure 1) [8].

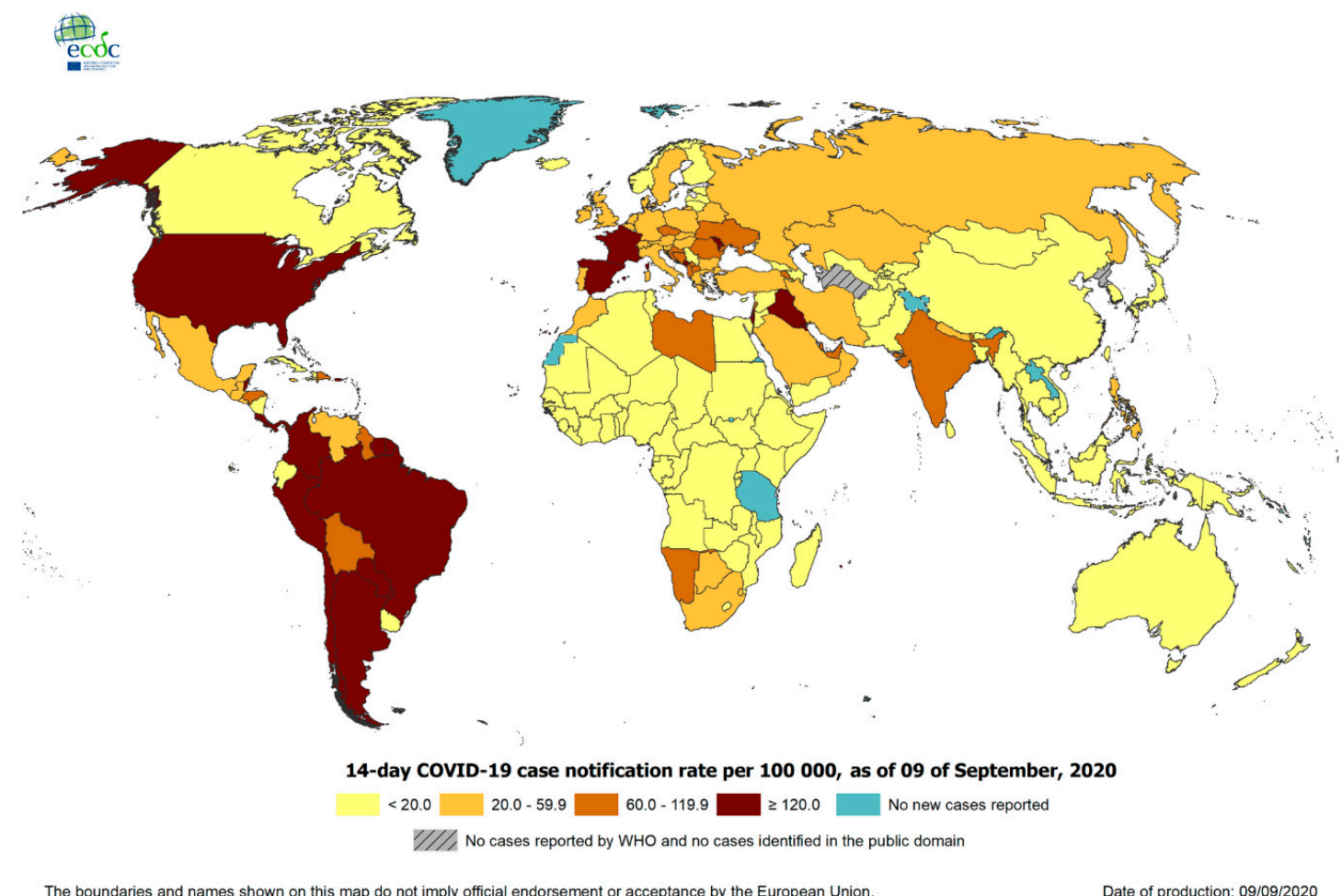

Figure 1. European Centre for Disease Prevention and Control report on the coronavirus (COVID-19) situation worldwide as of 9 September 2020 [8].

\subsection{Community Surveillance of the Virus Load}

Developed countries tend to have advanced infrastructure as compared to developing countries [31]. Similarly, in the detection of COVID-19 in sewage treatment systems, the method could be quickly adapted to detect viral loads in stools of asymptomatic and symptomatic patients in catchment areas because of the interconnectedness and properly constructed sewage systems linked to a community sewage treatment center [32]. However, in most developing countries, some communities do not have interconnected and centralized sewage systems to put into effect the WBE method of spotting the virus in sewage systems. For instance, BBC World reported on 14 March 2020, that nearly half of 1.2 billion people in India lacked access to toilet facilities (BBC News, 2020). While 49.8\% practiced open defecation, $46.9 \%$ had access to lavatories as the remaining $3.2 \%$ had access to public toilets. Upon investigation of the presence of the virus in sewage systems and possible signs of an imminent outbreak, the rundown of South Africa's municipal sewage systems poses a risk of infection to residents and nearby communities [33]. With streamlined and properly constructed sewage systems in developed countries, WBE is observed to be very consistent with the findings of other 
researchers [32-34]. For instance, wastewater was sampled at the Amsterdam Airport once a week in the first quarter of 2020 with results showing a positive detection of the virus RNA using a quantitative RT-PCR methodology four days after recording cases in the Netherlands [34]. Sodré et al. [35] further corroborate these findings, stating that "the detection of the virus in sewage, even when the COVID-19 prevalence is low gives an indication that sewage surveillance could be used to monitor the circulation of the virus in the population."

Further studies conducted showed that out of the 74 COVID-19 patients, $55 \%$ showed a prolonged presence of SARS-COV-2 in their faucal matter [36]. A mean value of 27.9 days as compared with a mean of 16.7 days in the respiratory samples of the 55\% in China was reported [34-36]. The clinical and WBE per-assay costs of screening may differ significantly depending on the geospatial regions, the labor cost differentiation prices, existing infrastructure, safety requirements, among others. Mao et al. [34] discovered that the cost per kit of clinical testing of the virus in patients could cost between USD 10 to 20 depending on the location of the patient with an average mean of USD 15 globally. As it stands now, approximately 30,000-600,000 of SARS-COV-2 viral genomes per mL of human excreta with a faucal load of 100-400 $\mathrm{g}$ has been reported [3,20]. Sodré et al. [35] also reported that the SARS-CoV-2 load to municipal wastewater is estimated to be associated with lower and upper bound estimates of 56.6 million to 11.3 billion viral genomes per infected person per day. This translates into concentrations of 0.15 to 141.5 million viral genomes per liter of wastewater generated in North America and Europe.

\subsection{Prevention of COVID-19 in Humans}

Appallingly, up until this point, there seems to be no viable formula for medicating the combination or use for SARS-CoV-2 disease cure, with the possible outcomes resulting in fatal provocative reactions and acute lung injury [37]. There have been several pieces of research conducted to remediate and control the absolute collapse of the immune system of infected patients. Hamidouche and Belmessabih [28] suggested that SARS-CoV-2 Mpro protease establishes one of the most appealing antiviral medication targets, particularly in the structure and advancement of SARS drugs. Further, Borges do Nascimento et al. [38] also noted that the Chinese treatment guidelines and the WHO's Centre for Disease Control and Prevention (CDC) had recommended drugs including one of the investigational agents (remdesivir), ritonavir or lopinavir. Up until now, there is no cure for the virus and, therefore, the WHO presents some guidelines as safety protocols for human protection and prevention of the virus as depicted in Figure 2. These include social distancing; lockdown (which is an extreme form of social distancing); hand hygiene practices, such as hand washing and sanitizing; symptom screening; cloth mask and cough etiquettes; testing, isolation, quarantine and contact tracing; and frequent fumigation and cleaning of the environment. As earlier stated, COVID-19 has unknown vaccine or cure, and its death rates are rising steeply. It is, therefore, imperative that precautionary measures are taken for the safety of the whole population [28]. Recent studies suggest that COVID-19 is aerosol or airborne and can stay in the air for more than $8 \mathrm{~h}$; hence, the wearing of masks is very important $[28,37,38]$. 


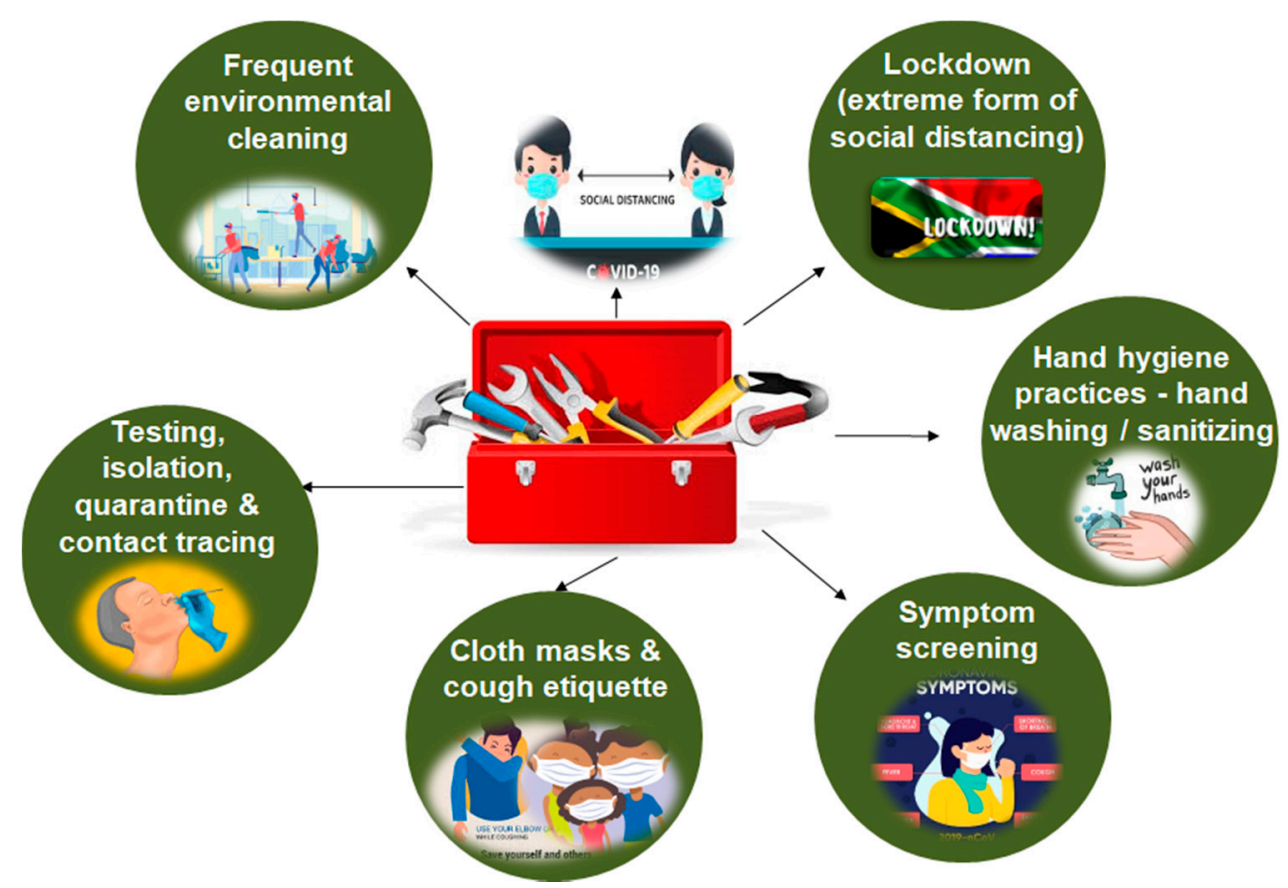

Figure 2. Safety protocols and etiquettes during COVID-19.

\section{SARS-COV-2 in Wastewater Possible Treatment Technologies}

As the end route of sanitization steps, excretion of COVID-19 patients and other administrative pre-requisites of COVID-19 are the sewage treatment plants and WWTPs. This has prompted the USA Occupational Safety and Health Administration (OSHA) to release new stringent rules and guidelines for wastewater and sewage workers based on data obtained from healthcare settings earlier this year [36-38]. Ahmed et al. [4] reported that coronaviruses, including SARS-COV2, responsible for the COVID-19 pandemic, could possibly remain infectious for days or even longer in sewage and drinking water. Apart from the cleansing and disinfection techniques applied in such as hospitals and clinics such as sterilization by ultraviolet radiation, and chlorination with peracetic acid or hypochlorous acid. This section presents possible wastewater treatment technologies and detection technologies of SARS-COV-2 in wastewater settings.

\subsection{SARS-COV-2 Possible Detection Techniques}

\subsubsection{Magnetic Nanotechnology}

Magnetic nanoparticles (Ferromagnetite) have been reported as good substrates for heavy metal adsorption from aqueous solutions [9,34]. The chemistry behind this mechanism could be attributed to the four unpaired electrons in the $3 \mathrm{~d}$ shell with an iron atom having a strong magnetic moment. $\mathrm{Fe}^{2+}$ ions have 4 unpaired electrons in their $3 \mathrm{~d}$ shell, and $\mathrm{Fe}^{3+}$ ions have five unpaired electrons in their $3 \mathrm{~d}$ shell. Magnetite nanoparticles are susceptible to air oxidation and can be easily aggregated in aqueous systems. The stabilization of the iron oxide nanoparticles by adding surfactants as a type of surface modification is desirable. In this context, ongoing application of magnetic nanoparticles in wastewater settings, which includes the removal of non-magnetic water pollutants like dissolved pollutants, algae, and viruses via magnetic separation has appeared to be very promising techniques [9].

For instance, a study conducted by Mao et al. [34] showed effective use of aptamer-conjugated magnetic nanoparticles for the removal of $\mathrm{HCV}$ particles from human plasma samples. Furthermore, magnetic particles coupled with biosensors have been employed for detecting viruses of biofilms in the sewage treatment system [2]. This presented an easy modification with functional groups which leads to the possibility to control their orientation after immobilization [24]. The improved 
utilization of established methods and the changing analytical techniques began incorporating nanoor micro-sized magnetic beads (MBs) [39]. Randazzo et al. [6] indicated that the presence of surface functional groups creates a speedy response to an applied magnetic field, uniform and high magnetite content, homogenous size distribution and colloidal stability of magnetic nanoparticles which are some of the specific properties of MBs in the analytical applications. The magnetic behavior associated with magnetic nanoparticles, mostly of ferromagnetic materials, enhances simple isolation of analytes from complex matrices such as environmental and biological samples [39]. This is carried out by connecting specific ligands on the outside of MBs and isolating the MB-bound analytes with the guide of an outer magnetic field. Additionally, with specifications, MBs could then function with different responsive groups, like tosyls, epoxyls, carboxyls, and amines which can be utilized to immobilize ligands with high affinity including antibodies, proteins, aptamers, among others, based on the accepted applications [6,39].

Recently, applications of magnetic separation have been introduced in biotechnology for analytical applications, separation of cells, sewage treatment, protein digestion and purifications $[6,9,34,39]$. Furthermore, integrating MBs with aptamers opens up additional opportunities in various applications including disease diagnosis using biosensors, cell imaging and labelling and magnetic resonance imaging, disease therapy, water purification, wastewater treatment, sewage treatment, and sample preparation [34,39]. As earlier stipulated, in aptamer-modified MB-based assays, aptamers are utilized as MBs and binding ligands generally utilized for separating the analyte from complex matrices. In aptamer-modified MBs, Surface-Enhanced Raman Scattering (SERS) sensing is employed in the analytical applications of diverse sensor designs (Figure 3).

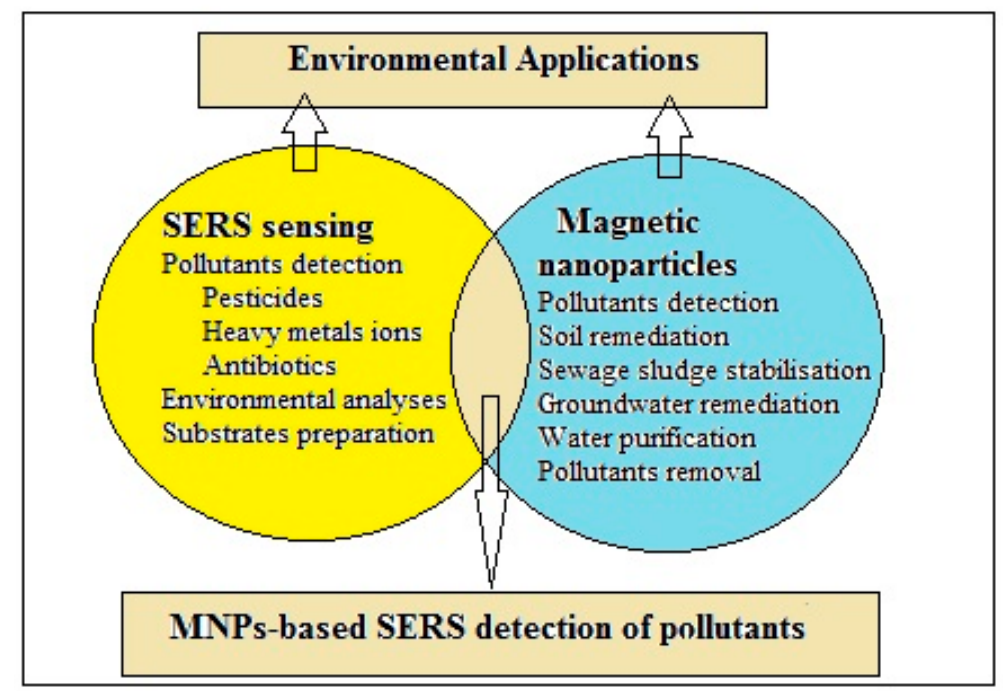

Figure 3. MNP-based SERS detection of pollutants adapted and modified from Pant et al. [39].

\subsubsection{Biosensor Technology}

Biosensors, as powerful and innovative analytical devices with biological sensing elements, have been employed in many potential fields, which includes drug discovery, diagnosis, biomedicine, food safety, environmental monitoring and security [1,30,40]. For instance, the term "contour" for glucose determination and that of "OneTouch" for glucose and cholesterol determination [40], is a lactose biosensor [30] and a portable system for enzyme immunoassay and polymerase chain reaction analysis [29]. It is reported that the first biosensor was invented by Clark and Lyons [41]. Additionally, the technical revolution in biosensors was found to be the discovery of genetically encoded or synthetic fluorescent biosensors in analyzing molecular mechanisms of biological processes [1,2,29,42]. The development of biosensors is limited by their low stability and the rapid degradation of biological components during storage and use [29]. This makes calibration difficult and reduces reliability. In contrast to biological components, their synthetic equivalents are chemically and thermally stable. 
Additionally, the utilization of biosensors has acquired paramount significance in the field of drug discovery, food safety standards, biomedicine, defense, security, and environmental monitoring [43]. For decades, it has led to the invention of precise and powerful analytical tools using biological sensing elements such as biosensor [42].

It is found that the topical advances in biological techniques and instrumentation involving fluorescence tagged to nanomaterials have increased the sensitivity limit of biosensors [42,44]. The adoption of aptamers or nucleotides, peptide arrays, antibodies, and molecule imprinted polymers could provide tools to develop innovative biosensors over classical methods [43]. The integrated approaches provide an improved perspective for the development of specific and sensitive biosensors with high regenerative potentials. Several biosensors ranging from nanomaterials, polymers to microbes could provide broader potential applications. The integrated strategies also involve multiple technologies ranging from electrochemical, electromechanical, and fluorescence with optical-based biosensors and genetically engineered microbes $[29,42,43]$. The majority of these biosensors have tremendous applications with prospects in disease diagnosis and medicine. The mandate and necessity for the use of biosensors for rapid analysis with cost-effectiveness require bio-fabrication that will pave the way to identify cellular to whole organism activity with a detection limit of high accuracy for single molecules [43]. Previous studies have reported that the rapid diagnosis of infectious diseases and apt initiation of appropriate treatment are typically assigned as determinants for the promotion of optimal clinical outcomes and that of the health of the public $[7,20,23]$. Other studies have reported that the conventional in vitro diagnostics for infectious diseases are time-consuming, requiring centralized laboratories, experienced personnel, and bulky equipment [32].

Recent advances in biosensor technologies have the potential to deliver point-of-care diagnostics that match or exceed conventional standards with regards to time, accuracy, and cost $[7,29,42]$. Despite the clinical need, the translation of biosensors from research laboratories to clinical applications remains limited to a few notable examples, such as the glucose sensor [42]. Some of the reported clinical challenges that are overcome by biosensors include sample preparation, matrix effects and system integration [28,29]. The vast range of sewage microbial diseases have been found to cause remarkable morbidity and mortality everywhere throughout the world. Sewage gives a perfect developing condition to various sorts of micro-organisms, including yeasts, fungi, algae, protozoa, viruses, and bacteria [6]. According to Mishra et al. [44], the level of heterotrophic, autotrophic, saprophytic, non-pathogenic, and pathogenic forms varies with their sources. Tobore [45] predicted that the concentration of some pathogenic viruses and parasites like Giardia and Cryptosporidium in wastewater is directly connected with the disease rate in the populace. This could narrow the general medical issues, other non-pathogenic faucal bacterial like RNA bacteriophages, total coliforms and E. coli mostly found in wastewater with a negligible effect on the lives of people [35,46]. Therefore, monitoring SARS-CoV-2 in sewage treatment facilities with biosensors in the sewage is useful. Leustean et al. [47] also added that the identification of waterborne infections is crucial to kill and control their harmful impact as pathogens. In essence, the recent invention of biosensors can be applied with magnetic nanomaterials to improve the precision and effectiveness of detecting several pollutants, including viruses in the sewage systems.

Types of Biosensors

Recently, different types of COVID-19 potential biosensors have been reported for point-of-care (POC) diagnosis of infectious diseases. These include sample-answer chip-, paper- and nanomaterial-based biosensors [1,2,42]. The chip-based biosensors are made of poly-methyl methacrylate (PMMA) for the detection of pathogens [42,43]. These biosensors have a high throughput of analysis by minimizing reagent consumption, owing to being automated and enhances the flow of a fluid with a small volume of samples to be manipulated with precision [43]. Additionally, their cost-effectiveness, high transparency and biocompatibility properties have attracted the attention of many researchers for advancement [7,20,29]. For instance, an integrated digital sample-answer 
chip-based biosensor to quantify nucleic acids is to be customized for future diagnosis of COVID-19 in wastewater [29,42].

Paper-based biosensors are also gaining significant usage attention for POC than the chip-based biosensors [2,42]. Due to their cost-effectiveness, user-friendliness and biodegradability, they can be applied on-site for POC testing in remote settings to achieve rapid results [2]. For instance, using a test strip to detect COVID-19 in patients' blood, serum and plasma samples [43]. These test strips consist of the following: (i) a sample pad to add patients samples; (ii) a conjugate pad containing antigen-coated COVID-19 with gold nanoparticles (gold-COVID-19); (iii) a nitrocellulose membrane that consists of a control line (coated with goat anti-rabbit IgG, an IgG test line coated with anti-human IgG, an IgM test line coated with anti-human IgM); and (iv) an absorbent pad that absorbs waste [7,42,43].

Further advancement of biosensors has led to the introduction of nanomaterials-based biosensors such as textile-based, film-based, magnetized nanomaterials (gold, iron, zinc), carbon and nanotubes-based (nanowire) biosensors for the detection of COVID-19 in wastewater settings [2,7,29,43]. The assay development is to improve the functionality and detection sensitivity of the conventional biosensors for commercialization and curbing of the economic threat of COVID-19 [42,43]. For instance, to increase the tunable hydrophobicity and interactions between integrated gold nanoparticle antibodies (AuNP-Ab) and the target for analysis [43].

\subsection{SARS-COV-2 Possible Wastewater Treatment Technologies}

\subsubsection{Membrane Bioreactor}

Membrane technology has emerged as a preferred choice for reclaiming water from different wastewater streams for reuse. With a significant reduction in the size of equipment, energy requirement and low capital cost, membrane technology offers many prospects in wastewater treatment [48]. According to Obotey Ezugbe and Rathilal [49], membrane technology has the potential of bridging the economic and sustainability gap, amid possibilities of low or no chemical usage, environmental friendliness, and easy accessibility to many. Thus, membrane technology has proven to be a more favorable option in wastewater treatment processes in recent times. Figure 4 shows the schematic representation of the different paths of the membrane process.

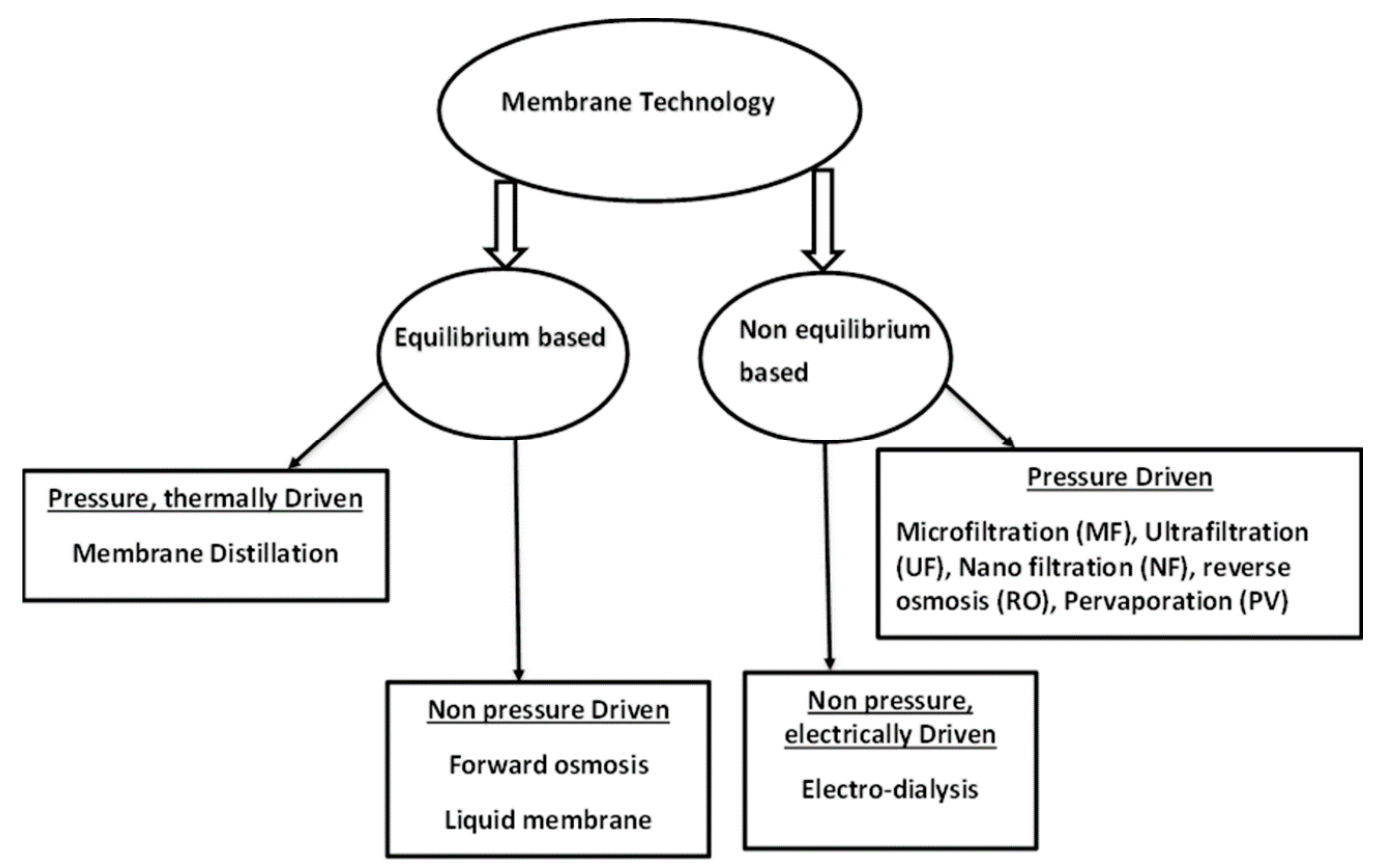

Figure 4. Schematic representation of the membrane processes adapted and modified from Obotey Ezugbe and Rathilal [49]. 
Over the past decades, membrane bioreactors (MBRs) have reached a significant market share in water and wastewater settings, which is expected to grow at a compound annual growth rate (CAGR) of $13.2 \%[13,49]$. This seems to be higher than that of other advanced technologies, thereby increasing its market value from USD 337 million in 2010 to USD 627 million in 2015 [13]. The main limitation for their widespread application is their high energy demand between 0.45 and $0.65 \mathrm{kWh} . \mathrm{m}^{-3}$ for the highest optimum operation from a demonstration plant, according to recent studies $[42,50]$. Past research articles had reported that, although MBR technology did not come into play when it was earlier introduced by Smith and his co-workers in the late 1960s, it has been playing an important role in wastewater treatment for reuse since the mid-1990s [42]. Rigorous regulations on effluent discharge and the reduction of membrane capital cost could be regarded as the principal drivers for the present widespread use of this technology worldwide [50]. The present emergence in the wastewater treatment market of the membrane bioreactors gives a clue of the degree of maturity reached by this technology. The most cited market analysis report indicates an annual growth rate of $9.0 \%$ and predicts a global market value of USD 3.7 billion by 2023 [2]. Predominantly outstanding in this case are China and some European countries with an implementation rate of over $50 \%$ and $20 \%$, respectively. The technological advancement in the urban wastewater market is also reflected under two major categories: the diversity of technology suppliers and the upward trend in plant size. It has been found that since 1990, the number of MBRs have grown exponentially with an estimate of over 50 different providers by the end of 2009 [48]. MBR processes make use of their microbiological and metabolic potential for treating wastewater. In relation to that, MBR processes are analogous to conventional activated sludge (CAS) processes [27,48]. These are designed and operated with much longer solids retention times (SRT) than that of CAS processes. Longer SRT operations result in different treatment performances and other associated situations [48]. Table 1 shows the advantages and disadvantages of MBR over CAS.

Table 1. Advantages and disadvantages of MBR over CAS; adapted from [27,48].

\begin{tabular}{ll}
\hline & 1. Production of high-quality treated water that is reusable in addition to removal \\
of most of the pathogenic bacteria and some viruses. \\
2. Low footprint due to the obviation of a secondary sedimentation tank and \\
smaller bioreactor size. \\
3. Reduces WAS production \\
4. Fine control of SRT
\end{tabular}

\section{Limitations of MBR}

The fundamental frameworks associated with an MBR includes microbiology, kinetics, stoichiometry and mass balance that is substantially different from CAS plant bioreactors with respect to design and operations [51]. MBR processes make use of microfiltration or ultrafiltration membranes to separate treated water from activated sludge (Figure 5), replacing gravity sedimentation tanks (or secondary sedimentation tanks) in CAS processes [48,51]. For simplicity, some advantages of MBRs include its compactness, higher effluent quality, a higher rate of degradation and the possibility to convert from existing conventionally active sludge purification. The disadvantages arise from aeration limitation, stress on sludge in external MBRs, fouling and higher costs in pricing [51]. Additionally, at low growth conditions, as is demanded in MBRs, other processes apart from microbial growth have to be taken into consideration. This is recognized as the maintenance energy requirement, endogenous respiration, and subsequent cryptic growth [52]. The commercialization of the largest MBRs with a peak design capacity higher than 50 MLD (mega liters per day) [42] and other plants are presented in Table 2. Conventionally, this involves activated sludge treatment together with a process filtration through a membrane with a pore size between $10 \mathrm{~nm}$ and 0.4 microns (micro/ultrafiltration), 
which enhances the sludge separation [42,52]. The membrane as a barrier retains all particles, colloids, bacteria, and viruses to provide complete treated water [13].

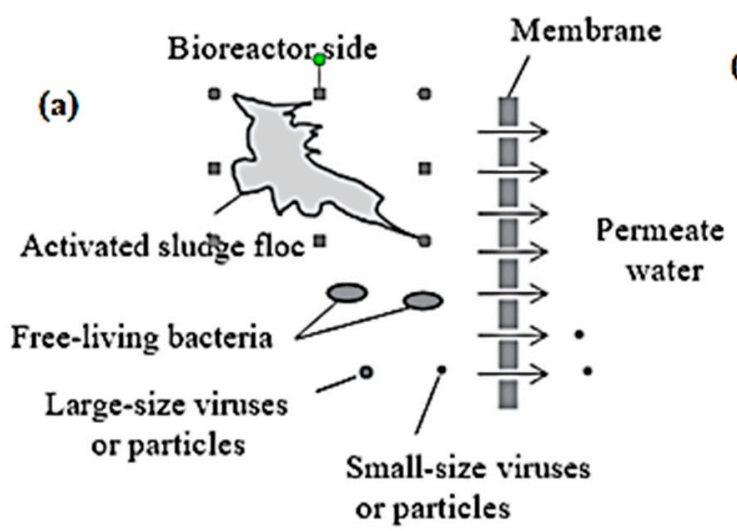

(b)

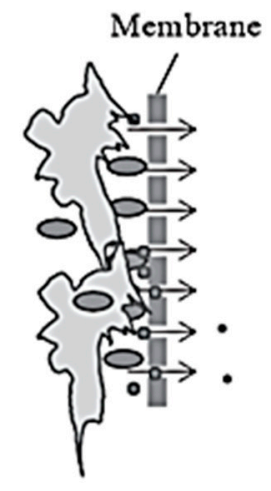

Figure 5. Schematic representation of the principles of the MBR process: (a) membrane filtration in MBR and (b) membrane fouling in MBR modified and adapted from [3].

Table 2. The largest 8 MBR plants adapted and modified from [13].

\begin{tabular}{cccc}
\hline Project & Technology & Date & * DMDF (MLD) \\
\hline Wenyu River, China & Asahi K/Beijing Origin Water & 2007 & 100 \\
Shending River, China & Beijing Origin Water & 2010 & 120 \\
Johns Creek, GA & GE Zenon & 2009 & 94 \\
Beixiaohe, China & Siemens & 2008 & 78 \\
Sabadell, Spain & Kubota & 2009 & 55 \\
Peoria, USA & GE Zenon & 2008 & 76 \\
Cleveland Bay, Australia & GE Zenon & 2007 & 75 \\
\hline
\end{tabular}

* DMDF: Design maximum daily flow (MLD: Megaliters per day)

Furthermore, there is limited information on the morphology and extracellular polymeric substance (EPS) production for total sludge retention and low ratios [53]. Additionally, the limitation of gravity sedimentation, which produces nearly particle-free clean effluents could be overcome with membrane separation technology. However, there have been reported cases of severe membrane fouling $[49,53]$. There is a continuous modification in membrane modules and membrane elements in enhancing the reduction in membrane fouling, which is a major challenge for membrane processes [54]. The leeway of combining two or more membrane processes, or with other forms of technology like coagulation, in an amalgam fashion is continuously being explored, advanced, and applied in many wastewater treatment facilities [54-56].

\section{MBR Configurations}

There are two major configurations of MBRs that are currently being used: side stream MBRs and immersed MBRs (Figure 6). The side stream MBR was the first to be introduced in the past decades [51-56]. It is important to understand that with the side stream MBR, the membranes are mounted outside the bioreactor, requiring an intermediate pumping system which transfers the biomass for filtration and residue from the filtration set up back to the bioreactor [51]. This principle is advantageous, in that the membrane module is easily accessible for cleaning; however, due to the high energy and pressure requirements, the side stream MBRs have had limited application in recent years compared to the submerged MBR [56]. The side stream configuration produces very high-quality effluent as the technology was applied to very limited cases such as industrial and leachate wastewater. Higher energy costs associated with mixed liquor recirculation, membrane fouling and high membrane capital costs restrained the spread of this technology to general applications such as the treatment of municipal wastewater $[51,56,57]$. 


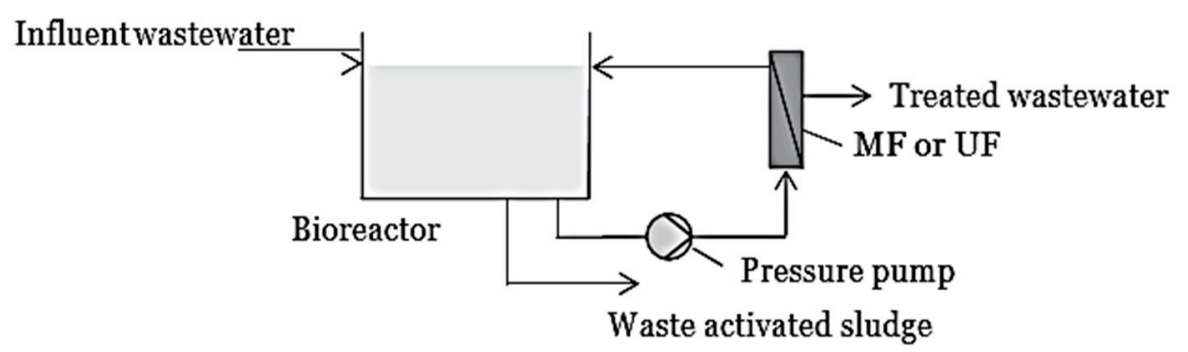

(a)

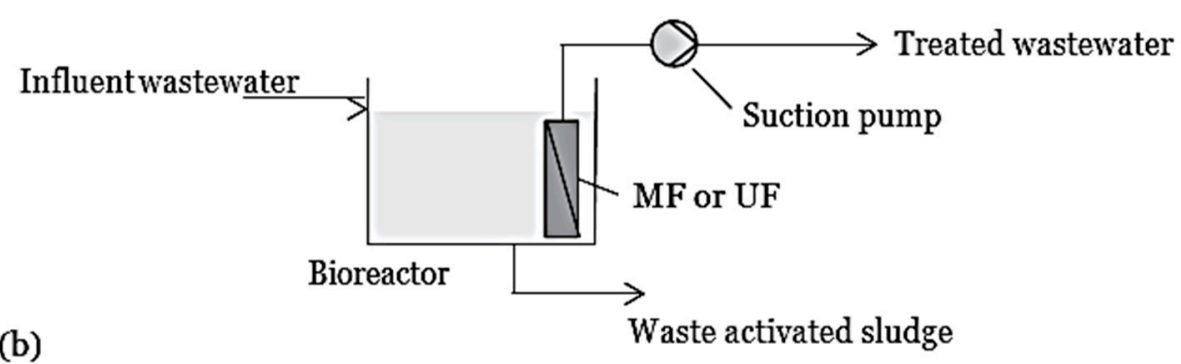

Figure 6. Two operational types of MBR technology: (a) side-stream configuration and (b) submersed configuration $[5,51]$.

\section{Micro-Organisms in Bioreactors}

Micro-organisms are commonly defined as small life forms that cannot be easily identified by the naked eye but are observed with the help of a microscope [58,59]. Traditionally, micro-organisms are classified into prokaryotic and eukaryotic micro-organisms based on the existence of a membrane-bound nucleus. Eukaryotic micro-organisms have an intracellular membrane-bound nucleus that contains nuclear materials, while prokaryotic micro-organisms have their nuclear materials spread in the cytoplasm (e.g., no membrane-bound nucleus). A comparison between these kinds of micro-organisms is presented in Table 3. Additional properties that differentiate them include cell size, membrane-bound organelles, cell wall, cell division, and sexual reproduction. Prokaryotic micro-organisms include bacteria and archaea, while eukaryotic micro-organisms include fungi, algae, protozoa, and animals. These micro-organisms play a vital role in bioreactors, such that organic pollutants are mostly oxidized into carbon dioxide and water, while ammonia (an inorganic pollutant) is oxidized into nitrate [60]. Various types of micro-organisms can exist in bioreactors. One main feature of micro-organisms in environmental engineering systems, including MBR, is that they are structured into communities consisting of diverse species in an open system, where diverse micro-organisms are continuously fed into a bioreactor via influent wastewater and from the atmosphere [57,61]. Nevertheless, specific types of micro-organisms can be enriched in bioreactors by imposing specific reactor designs and operational conditions. The microbial community structure is believed to be important in determining the function, performance, and stability of bioreactors $[61,62]$.

Table 3. Comparison between Prokaryotic and Eukaryotic Microorganisms [58].

\begin{tabular}{ccc}
\hline Micro-Organisms & Prokaryotes & Eukaryotes \\
\hline Membrane-bound nucleus & Absent & Present \\
Cell size & $0.1-2 \mu \mathrm{m}$ & $10-100 \mu \mathrm{m}$ \\
Membrane-bound organelles & Absent & Present (e.g., mitochondria, \\
Cell wall & chloroplast, and Golgi complex) \\
Pili & Present & Not all \\
Cell division & Present & Absent \\
Sexual reproduction & Binary fission & Mitosis, meiosis \\
& Asexual & Sexual, asexual \\
\hline
\end{tabular}


Application of MBR on Viral Loads in Wastewater

Membrane-coupled bioreactors have been used as one alternative to the conventional anaerobic digestion process. Thus, MBR has the ability to retain microbial community to degrade organics, produce high solid and pathogen-free effluents as well as the capacity to recover the energy potential of soluble organic matter [51,61]. MBR technology has demonstrated to be a more effective system in removing pathological micro-organisms, including SARS-COV-2 [63]. Researchers have determined the diameter of SARS-COV-2 to range between 60 and $140 \mathrm{~nm}$ [62-64], where viral load in WWTP has been found to range between 2 and $3.10^{3}$ copies $/ \mathrm{mL}$, depending on the level of the epidemic $[64,65]$. MBR has been reported to efficiently remove viral loads as low as $27 \mu \mathrm{m}$ [66], which is 60 times smaller than SARS-COV-2 in WWTP [63]. Therefore, its efficiency in removing the viral load is expected to be higher. This technology can also shorten the reaction time (approximately $1.5 \mathrm{~min}, 2.5$ to $5 \%$ of traditional wastewater treatment process), viably save disinfectant consumption (chlorine addition can diminish to $1.0 \mathrm{mg} / \mathrm{L}$ ), and achieve a decent impact of inactivation of micro-organism $[63,65]$. Higher disinfection viability is accomplished in MBR effluents at a lower dose of disinfectant with fewer disinfection by-products (DBPs) [66]. In the past, MBR was considered inappropriate in WWTP due to its high operating cost; however, decreasing cost and stringent standards are making the use of MBR systems more economically viable [61,63]. For instance, when the limit of MBR plants is increased from 20 to $1000 \mathrm{~m}^{3} / \mathrm{d}$, their operating cost is projected to reduce sharply [67].

\subsubsection{Advanced Oxidation Process}

Current emerging micropollutants contaminants (RNA of COVID-19, pesticides, antibiotics, endocrine disrupting compounds) in WWTPs discharges impacts on the likelihood to reuse these waters after treatment $[68,69]$. When aquatic animals inject the micropollutants contaminants, they alter their endocrine system due to the endocrine-disrupting compounds [70,71]. A possible prospect for removing micropollutants from tertiary WWTP is hydrogen peroxide $(\mathrm{H} 2 \mathrm{O} 2)$ /ultraviolet (UV) as an advanced oxidation process (es) (AOPs) [72]. Recently, the Gold Bar Wastewater Treatment Plant applied this method in Edmonton, Canada, to treat secondary sewage [73]. Since then, the process has received much attention because it uses hydroxyl radical $(\bullet \mathrm{OH})$, which is highly reactive to destruct intractable chemicals found in wastewater [74]. Hydroxyl radicals are known to bombard organic molecules nonselective and rapidly. Additionally, the process offers other diverse approaches of producing hydroxyl radicals making it more versatile and consequently gives a better approach to adhering to strict guidelines during wastewater treatment. AOPs which include Photocatalysis, ultrasonic process, Fenton and photo-Fenton processes $\left(\mathrm{Fe}_{2}{ }^{+} / \mathrm{UV} / \mathrm{H}_{2} \mathrm{O}_{2}\right.$ and $\left.\mathrm{Fe}_{2}{ }^{+} / \mathrm{H}_{2} \mathrm{O}_{2}\right), \mathrm{H}_{2} \mathrm{O}_{2} / \mathrm{UV}$, ozone combined with catalysts $\left(\mathrm{O}_{3} /\right.$ catalysts $), \mathrm{UV}$ irradiation $\left(\mathrm{O}_{3} / \mathrm{UV}\right)$ and ozone combined with hydrogen peroxide $\left(\mathrm{O}_{3} / \mathrm{H}_{2} \mathrm{O}_{2}\right)$ or both $\left(\mathrm{UV} / \mathrm{H}_{2} \mathrm{O}_{2} / \mathrm{O}_{3}\right)$ have been effectively utilized in treating wastewater $[68,69,74,75]$. A remarkable feature realized during the process was the eco-friendliness of the end-product, giving it a more efficient outlook to mineralize a broad spectrum of organic pollutants, including COVID-19. The process is eco-friendly, which can rely on solar energy instead of artificial light sources which is hazardous and costly $[69,75]$. Furthermore, due to the highly reactive nature of $\bullet \mathrm{OH}$, it can attack almost any organic materials without any discernment. The advantages and disadvantages of AOPs in WWTPs are tabulated in Table 4.

\section{Application of AOP on Viral Loads in Wastewater}

As AOP generates high influential oxidative agents such as hydroxide $\left(\mathrm{OH}^{-}\right)$, yet more explicitly, a neutral variant of hydroxyl radical $(\bullet \mathrm{OH})[68,69]$. In essence, AOP oxidation potential is twice that of chlorine (commonly used disinfectant), therefore employing AOP as a polishing step in WWTPs is useful [10]. Hydroxyl radicals are the main impetuses behind many AOPs. $U V, \mathrm{H}_{2} \mathrm{O}_{2}$ and $\mathrm{O}_{3}$ are regularly utilized in different combinations to create $\bullet \mathrm{OH}$ in adequate quantities to debase organic and some inorganic pollutants [72,73]. The process can diminish these pollutant concentrations, 
conceivably from hundreds of parts per million (ppm) to only a couple of parts per billion (ppb) [73,74]. These radicals are non-selective; therefore, they practically attack all organic materials. After, they form intermediates with the $\bullet \mathrm{OH}$ radical [74]. Thereafter, the intermediates react with the oxidants and mineralize into stable compounds. For instance, platinized sulfated $\mathrm{TiO}_{2}\left(\mathrm{TiO}_{2} / \mathrm{Pt}\right)$ and undoped $\mathrm{TiO}_{2}$ was investigated with micro-organisms loaded over photocatalyst films from aerosols to load influenza A $\left(\mathrm{H}_{3} \mathrm{~N}_{2}\right)$, vaccinia virus, Bacillus thuringiensis and Mycobacterium smegmatis [76]. The study showed that $90 \%$ of the inactivation was reached in 30 min UVA irradiation on $\mathrm{TiO}_{2}$ and to $99.8 \%$ on $\mathrm{TiO}_{2} / \mathrm{Pt}$. TiO $/ 2 / \mathrm{Pt}$ showed increased mineralization rate and inactivation was likely due to charge carrier separation in doped semiconductor photocatalyst. The $\mathrm{OH}$ molecule has a very fast reaction rate of the total oxidants used to treat wastewater due to their non-selective nature and its high oxidation potential $[75,77]$. The fast reactions led to much lower retention times than other traditional treatment processes. One of the issues with chlorine disinfection is the profoundly toxic byproducts (DPBs) that can result after treatment. To forestall these results, an additional de-chlorination step is frequently required. The $\bullet \mathrm{OH}$ molecule can combine to produce water. The most significant issue would be with excess peroxide and bromate formation, nevertheless, these can be managed in a well-structured AOP system $[10,76]$. Concerning the treatment of SARS-COV-2 in wastewater treatment plants, some of these experimental observations about SARS-COV-2 or other derivatives of CoVs in WWTPs have been shown in Table 5. Wurtzer et al. [78] and Randazzo et al. [79] found positivity of treating wastewater with a viral load of $5.40 \log _{10}$ copies/L.

\subsection{Summary}

In summary, from the extant literature on the current pandemic which has held the world in an apocalyptic predicament, the paper found that sewage treatment systems could be a possible arena to keep a surveillance on the outbreak of the SARS-CoV-2 in communities around the globe. Nevertheless, most of the sewage systems appear oblique in impoverished regions, and appreciable in developing and developed countries due to their centralized and organized sewage systems. Additional studies showed that the virus could remain infectious for days in sewage and drinking water and, therefore, an effective method of eradicating the virus loads should be adopted. Additionally, there is cost, delay and unrelenting issues of insufficient diagnostic testing of COVID-19 in poor regions; therefore, this study found the science of wastewater-based epidemiology (WBE) as a viable approach to help identify hotspot areas of COVID-19 in remote communities and populated cities. Thus, by effective sampling and monitoring of the viral RNA in wastewater to assess virus occurrences, early warning and the spread in defined populations seem very promising and economical. However, there is still limited knowledge on the optimized and standardized protocol to enhance the detection and quantification of the SARS-COV-2 in wastewater, which calls for future works. Furthermore, the conventional RT-PCR techniques used for quantitative analysis was found to be time-consuming, labor-intensive and remotely unavailable. Therefore, biosensors were explored, and due to its cost-effectiveness, simplicity, rapidity and portability, was found to be the alternative to real-time monitoring (RT-PCR) of the COVID-19 infections. This included chip-, paper- and nanoparticle-based biosensors, which have been employed to detect nucleic acids of pathogens and human antibodies against the pathogens by integrating sample-answer process units of a biosensor. Additional assay sensitivity, simplicity and performance of the biosensors can be improved by either magnetic nano-based materials (gold, iron, graphene, and nanotubes) or enzyme-based materials to enhance the stability of the RNA in the sample.

With the pressing need for a breakthrough to develop a cure or vaccine for COVID-19, the remediation of wastewater cannot be left out. Thus, the end route of wastewater and human excretion is the wastewater treatment plants. This study found the WBE approach as a possible way to monitor the spread of the COVID-19. Additionally, integrating emerging and robust technologies like magnetic nanotechnology, biosensing and membrane bioreactors or AOPs into the conventional treatment systems could possibly mitigate the threat posed by emerging contaminants as well as the SARS-COV-2 RNA (Table 5). 
Table 4. Advantages and Disadvantages of AOPs in WWTPs.

\begin{tabular}{|c|c|}
\hline Advantages & Disadvantages \\
\hline $\begin{array}{c}\text { Converts organic materials into stable } \\
\text { inorganic compounds }\end{array}$ & Residual peroxide removal may need to be considered \\
\hline $\begin{array}{c}\text { Treat nearly all organic compounds and remove } \\
\text { some heavy metals }\end{array}$ & Complex chemistry tailored to specific contaminants \\
\hline $\begin{array}{l}\text { Do not introduce new harmful substances } \\
\text { theoretically into the water }\end{array}$ & Relatively high capital and maintenance \\
\hline $\begin{array}{c}\text { No sludge production as with biological or } \\
\text { chemical processes }\end{array}$ & Energy intensive \\
\hline $\begin{array}{c}\text { Does not concentrate waste for further treatment } \\
\text { Disinfection of pathogens especially using UV } \\
\text { Rapid and robust technology }\end{array}$ & \\
\hline
\end{tabular}

Table 5. Experimental observations about SARS-COV-2 or derived from other CoVs in WWTPs; Adapted from $[65,78,79]$.

\begin{tabular}{|c|c|c|}
\hline Technology & $\begin{array}{l}\text { Experimental Observations about } \\
\text { SARS-CoV-2 or Derived from Other CoVs }\end{array}$ & Laws, Mechanisms and Principles \\
\hline $\begin{array}{l}\text { Membrane Biological } \\
\text { Reactor (MBR) }\end{array}$ & $\begin{array}{l}3.9,5.1 \text { and } 5.5 \log \text { reduction of human } \\
\text { norovirus and enterovirus and human } \\
\text { adenovirus, respectively was obtained in } \\
\text { MBRs with absolute pore size of } 0.1 \mu \mathrm{m}\end{array}$ & $\begin{array}{l}\text { Microfiltration (greater than } 0.1 \mu \mathrm{m} \text { ) is } \\
\text { partially effective and might need a } \\
\text { further step of disinfection. } \\
\text { ultrafiltration (greater than } 0.01 \mu \mathrm{m} \text { ), } \\
\text { is advised in virus separation }\end{array}$ \\
\hline $\begin{array}{l}\text { Disinfection with chlorine } \\
\text { dioxide or free chlorine }\end{array}$ & $\begin{array}{l}\text { Free residue chlorine of over } 2.2 \mathrm{mg} / \mathrm{L} \text { is } \\
\text { required for chlorine dioxide for totally } \\
\text { inactivating SARS-CoV (nevertheless, E. } \\
\text { coli is not totally inactivated). } \\
\text { The dosage of free chlorine (hypochlorous } \\
\text { acid) should ensure free residue chlorine } \\
\text { over } 0.5 \text { ppm, to affirm that chlorine has not } \\
\text { been totally exhausted and guarantee total } \\
\text { inactivation of SARS-CoV to control } \\
\text { the virus. } \\
\text { SARS-CoV in wastewater is more } \\
\text { susceptible to chlorine dioxide and sodium } \\
\text { hypochlorite than Escherichia coli }\end{array}$ & $\begin{array}{l}\text { Inactivation is because of the reaction } \\
\text { with proteins in the nucleocapsid } \\
\text { rather than membrane lipids or } \\
\text { the genome }\end{array}$ \\
\hline UVC light & $\begin{array}{l}\text { Non-enveloped viruses appear to have } \\
\text { higher susceptibility to UVC light than } \\
\text { enveloped viruses } \\
\text { Inactivation in sludge is akin to wastewater } \\
\text { ( } 3 \text { log in } 2-4 \text { days) }\end{array}$ & $\begin{array}{c}\text { Inactivation essentially focuses on the } \\
\text { genome, while lipid film do not shield } \\
\text { viruses from the radiation }\end{array}$ \\
\hline $\begin{array}{l}\text { Primary and } \\
\text { Secondary settling }\end{array}$ & $\begin{array}{l}\text { a huge part of CoVs, is probably going to be } \\
\text { available in the primary or } \\
\text { secondary sludge } \\
6 \% \text { of non-enveloped viruses absorbed to } \\
\text { solids, compared to } 26 \% \text { of } \\
\text { enveloped viruses }\end{array}$ & $\begin{array}{l}\text { The hydrophobicity of the viral } \\
\text { envelope makes it less soluble in } \\
\text { water and they will in general adhere } \\
\text { to solids and concentrate in sludge. }\end{array}$ \\
\hline $\begin{array}{l}\text { Thermophilic and } \\
\text { mesophilic anaerobic } \\
\text { digestion }\end{array}$ & $\begin{array}{l}\text { Ammonia may act as a virucidal agent and } \\
\text { poliovirus lose infectivity in anaerobic } \\
\text { digestion at } 28^{\circ} \mathrm{C} \text {. } \\
\text { For anaerobic digestion, SARS-CoVs } \\
\text { infectivity is lost at temperature of } 56^{\circ} \mathrm{C} \text { for } \\
\quad 90 \text { min } \\
\text { Human CoV was detected in sludge's pre } \\
\text { and post anaerobic digestion }\end{array}$ & $\begin{array}{c}\text { Mesophilic digestion is much less } \\
\text { effective against non-enveloped } \\
\text { viruses than thermophilic } \\
\text { aerobic digestion } \\
\text { higher inactivation of CoVs is normal } \\
\text { in anaerobic digestion in light of the } \\
\text { fact that CoVs are substantially more } \\
\text { delicate to warm temperature } \\
\text { than poliovirus }\end{array}$ \\
\hline
\end{tabular}

\section{Conclusions and Recommendations}

This paper reviewed recent literature on the fate of COVID-19 in wastewater treatment systems and its emerging wastewater treatment technologies. In the midst of COVID-19 wastewater remediation, magnetic nanomaterials were found to be promising (biomagnetic separation, immunoassays, 
and medical imaging techniques) to provide opportunities to effectively target emerging contaminants that the conventional systems fail to remove. Thus, contaminant-loaded magnetic particles could be easily separated from the solution via an external magnetic field. Thereby, employing them in the wastewater treatment settings can enhance the stability of the viral RNA and other pathogens for the biosensor detections. Comprehensive studies on the toxicity of magnetic nanoparticles have proven to have little or no negative environmental impacts. Hence, integrating magnetized nanomaterials into the wastewater treatment settings, due to their super-magnetic properties, could facilitate the treatment and separations, while the rest of the composite is meant to provide a high surface area for the adsorption of the virus RNA for detection and quantification. Therefore, integrating magnetic biosensor diagnostics into wastewater treatment systems, via wastewater-based epidemiology (WBE) could be a possible way to investigate the spread of COVID-19 in communities around the globe for health policy development and to minimize the diagnostic cost of testing. Additionally, the long-term assessment of AOP $\left(\mathrm{UV} / \mathrm{H}_{2} \mathrm{O}_{2}\right)$ has proven to be economically viable for degrading endocrine-disrupting compounds and removing them in wastewater which gives hope for $\mathrm{UV} /$ magnetized $\mathrm{TiO}_{2}$ photocatalysis to inactivate RNA of COVID-19 on adsorbed surface of sludge.

Other recommendations and future works include:

- In the application of WBE, which requires routine sampling for diagnostic testing, all safe work protocols and effective personal protective equipment are encouraged to be used to protect personnel from SARS-CoV-2 exposure.

- To avoid discrepancy of results, future work of developing optimized and standardized protocols for detection and quantification of SARS-CoV-2 in wastewater is crucial. This assay needs to be compared and connected with centralized hospital laboratories to help generate effective regional reports.

- To improve the assay of biosensors with the aforementioned capabilities to mitigate and safeguard COVID-19's spread, its sensitivity and detection with magnetic nano-based materials are recommended. Future work can focus on integrating biosensors with biosecurity coupled with smart-phone apps connected to a centralized hospital database to help track carrier status.

- The prospects of photocatalysis to inactivate SARS-CoV-2 in wastewater settings is very high, owing to its appreciable used for sterilization of clinical devices, degradation of protein and virus RNA. Therefore, future research should focus on its safe nanotechnology and bioengineering line to combat the COVID-19 pandemic.

Author Contributions: E.K.T. and M.O.A., both contributed equally to conceptualizing, writing, and revising the manuscript. E.K.A. and S.R. did the editing and proofreading. All authors have read and agreed to the published version of the manuscript.

Funding: This research received no external funding.

Acknowledgments: The authors are thankful to the Durban University of Technology, South Africa for using their available resource facilities. Water Research Commission of South Africa for their support on the project identification WRC Project: C2019/2020-00212.

Conflicts of Interest: The authors declare no conflict of interest.

\section{References}

1. Barcelo, D. An environmental and health perspective for COVID-19 outbreak: Meteorology and air quality influence, sewage epidemiology indicator, hospitals disinfection, drug therapies and recommendations. J. Environ. Chem. Eng. 2020, 8, 104006. [CrossRef] [PubMed]

2. Ghernaout, D.; Elboughdiri, N. Urgent proposals for disinfecting hospital wastewaters during COVID-19 Pandemic. Open Access Libr. J. 2020, 7, 1-18. [CrossRef]

3. Hart, O.E.; Halden, R.U. Computational analysis of SARS-CoV-2/COVID-19 surveillance by wastewater-based epidemiology locally and globally: Feasibility, economy, opportunities and challenges. Sci. Total Environ. 2020, 730, 138875. [CrossRef] [PubMed] 
4. Ahmed, W.; Angel, N.; Edson, J.; Bibby, K.; Bivins, A.; O’Brien, J.W.; Choi, P.M.; Kitajima, M.; Simpson, S.L.; $\mathrm{Li}$, J.; et al. First confirmed detection of SARS-CoV-2 in untreated wastewater in Australia: A proof of concept for the wastewater surveillance of COVID-19 in the community. Sci. Total Environ. 2020, 728, 138764. [CrossRef] [PubMed]

5. Kitajima, M.; Ahmed, W.; Bibby, K.; Carducci, A.; Gerba, C.P.; Hamilton, K.A.; Haramoto, E.; Rose, J.B. SARS-CoV-2 in wastewater: State of the knowledge and research needs. Sci. Total Environ. 2020, 739, 139076. [CrossRef]

6. Randazzo, W.; Cuevas-Ferrando, E.; Sanjuan, R.; Domingo-Calap, P.; Sanchez, G. Metropolitan wastewater analysis for COVID-19 epidemiological surveillance. Int. J. Hyg. Environ. Health 2020, 230, 113621. [CrossRef]

7. Annalaura, C.; Ileana, F.; Dasheng, L.; Marco, V. Making waves: Coronavirus detection, presence and persistence in the water environment: State of the art and knowledge needs for public health. Water Res. 2020, 179, 115907.

8. Nghiem, L.D.; Morgan, B.; Donner, E.; Short, M.D. The COVID-19 pandemic: Considerations for the waste and wastewater services sector. Case Stud. Chem. Environ. Eng. 2020, 1, 100006. [CrossRef]

9. Venugopal, A.; Ganesan, H.; Raja, S.S.S.; Govindasamy, V.; Arunachalam, M.; Narayanasamy, A.; Sivaprakash, P.; Rahman, P.K.S.M.; Gopalakrishnan, A.V.; Siama, Z.; et al. Novel wastewater surveillance strategy for early detection of COVID-19 hotspots. Curr. Opin. Environ. Sci. Health 2020, 17, 8-13. [CrossRef]

10. Quevedo-león, R.; Bastías-Montes, J.; Espinoza-Tellez, T.; Ronceros, B.; Balic, I.; Muñoz, O. Inactivation of Coronaviruses in food industry: The use of inorganic and organic disinfectants, ozone, and UV radiation. Sci. Agropecu. 2020, 11, 257-266. [CrossRef]

11. Daughton, C.G. Wastewater surveillance for population-wide Covid-19: The present and future. Sci. Total Environ. 2020, 736, 139631. [CrossRef] [PubMed]

12. Vera, L.; González, E.; Díaz, O.; Delgado, S. Application of a backwashing strategy based on transmembrane pressure set-point in a tertiary submerged membrane bioreactor. J. Membr. Sci. 2014, 470, 504-512. [CrossRef]

13. Delgado, S.; Villarroel, R.; González, E.; Morales, M. Aerobic membrane bioreactor for wastewater treatment-Performance under substrate-limited conditions. In Biomass-Detection Production and Usage; InTech: Rijeka, Croatia, 2011. [CrossRef]

14. Nayak, S.L.; Sethi, S.; Sharma, R.; Sharma; Singh, S.; Singh, D. Aqueous ozone controls decay and maintains quality attributes of strawberry (Fragaria $\times$ ananassa Duch.). J. Food Sci. Technol. 2020, 57, 319-326. [CrossRef] [PubMed]

15. Figueroa, A.; Hauck, R.; Saldias-Rodriguez, J.; Gallardo, R.A. Combination of quaternary ammonia and glutaraldehyde as a disinfectant against enveloped and non-enveloped viruses. J. Appl. Poult. Res. 2017, 26, 491-497. [CrossRef]

16. Lee, H.-M.; Yang, J.-S.; Yoon, S.-R.; Lee, J.Y.; Kim, S.-J.; Lee, H.-W.; Kim, S.H.; Ha, J.-H. Immunomagnetic separation combined with RT-qPCR for evaluating the effect of disinfectant treatments against norovirus on food contact surfaces. Food Sci. Technol. 2018, 97, 83-86. [CrossRef]

17. Zhu, Z.; Guo, Y.; Yu, P.; Wang, X.; Zhang, X.; Dong, W.; Liu, X.; Guo, C. Chlorine dioxide inhibits the replication of porcine reproductive and respiratory syndrome virus by blocking viral attachment. Infect. Genet. Evol. 2019, 67, 78-87. [CrossRef]

18. Brons, J.; Bierman, A.; White, R.; Benner, K.; Deng, L.; Rea, M. An assessment of a hybrid lighting system that employs ultraviolet-A for mitigating healthcare-associated infections in a newborn intensive care unit. Light. Res. Technol. 2020. [CrossRef]

19. Ha, J.-H.; Kim, M.L.; Choi, C.; Choi, I.-S.; Myoung, J.; Ha, S.-D. Recovery of structurally intact norovirus from food-contact surfaces. Food Control 2015, 47, 564-568. [CrossRef]

20. Bivins, A.; North, D.; Ahmad, A.; Ahmed, W.; Alm, E.; Been, F.; Bhattacharya, P.; Bijlsma, L.; Boehm, A.N.; Brown, J.; et al. Wastewater-based epidemiology: Global collaborative to maximize contributions in the fight against COVID-19. Environ. Sci. Technol. 2020, 54, 7754-7757. [CrossRef]

21. Sarwar, S.; Waheed, R.; Sarwar, S.; Khan, A. COVID-19 challenges to Pakistan: Is GIS analysis useful to draw solutions? Sci. Total Environ. 2020, 730, 139089. [CrossRef]

22. Díaz, O.; González, L.; Vera, L.; Porlán, J.; Rodríguez-Sevilla, C. Afonso-Olivares; Sosa-Ferrera, Z.; Santana-Rodríguez, J.J. Nanofiltration/reverse ósmosis as pretreatment technique for water reuse: Ultrafiltration versus tertiary membrane reactor. Clean Soil Air Water 2017, 45. [CrossRef]

23. Kocamemi, B.A.; Kurt, H.; Sait, A.; Sarac, F.; Saatci, A.M.; Pakdemirli, B. SARS-CoV-2 Detection in Istanbul wastewater treatment plant sludges. medRxiv 2020, medRxiv:medrxiv20099358. Available online: https://www.medrxiv.org/content/about-medrxiv (accessed on 17 September 2020). [CrossRef] 
24. Silverman, A.I.; Boehm, A.B. Systematic review and meta-analysis of the persistence and disinfection of human coronaviruses and their viral surrogates in water and wastewater. Environ. Sci. Technol. Lett. 2020, 7 , 544-553. [CrossRef]

25. Hata, A.; Honda, A. Potential sensitivity of wastewater monitoring for SARS-CoV-2: Comparison with Norovirus Cases. Environ. Sci. Technol. 2020. [CrossRef] [PubMed]

26. Hernández, F.; Castiglioni, S.; Covaci, A.; de Voogt, P.; Emke, E.; Kasprzyk-Hordern, B.; Ort, C.; Reid, M.; Sancho, J.V.; Thomas, K.V.; et al. Mass spectrometric strategies for the investigation of biomarkers of illicit drug use in wastewater. Mass Spectrom. Rev. 2018, 37, 258-280. [CrossRef] [PubMed]

27. Zhang, R.; Li, Y.; Zhang, A.L.; Wang, Y.; Molina, M.J. Identifying airborne transmission as the dominant route for the spread of COVID-19. Proc. Natl. Acad. Sci. USA 2020, 117, 14857-14863. [CrossRef] [PubMed]

28. Hamidouche, M.; Belmessabih, N. Time Course of COVID-19 epidemic in Algeria: Retrospective estimate of the actual burden. medRxiv 2020, medRxiv:medrxiv20109231. Available online: https://www.medrxiv.org/ content/10.1101/2020.05.22.20109231v5 (accessed on 17 September 2020).

29. Kozitsina, A.N.; Svalova, T.S.; Malysheva, N.N.; Okhokhonin, A.V.; Vidrevich, M.B.; Brainina, K.Z. Sensors based on bio and biomimetic receptors in medical diagnostic, environment, and food analysis. Biosensors 2018, 8, 35. [CrossRef]

30. Idumah, C.I.; Hassan, A.; Ihuoma, D.E. Recently emerging trends in polymer nanocomposites packaging materials. Polym. Plast. Technol. Mater. 2019, 58, 1054-1109. [CrossRef]

31. Fan, R.; Andrew, T.L. Perspective-Challenges in developing wearable electrochemical sensors for longitudinal health monitoring. J. Electrochem. Soc. 2020, 167, 037542. [CrossRef]

32. Schultz, J.; Uddin, Z.; Singh, G.; Howlader, M.M. Glutamate sensing in biofluids: Recent advances and research challenges of electrochemical sensors. Analyst 2020, 145, 321-347. [CrossRef]

33. Rimoldi, S.G.; Stefani, F.; Gigantiello, A.; Polesello, S.; Comandatore, F.; Mileto, D.; Maresca, M.; Longobardi, C.; Mancon, A.; Romeri, F.; et al. Presence and vitality of SARS-CoV-2 virus in wastewaters and rivers. medRxiv 2020, medRxiv:medrxiv20086009. Available online: https://www.medrxiv.org/search/Presence\%252Band\%252Bvitality\%252Bof\%252BSARS-CoV-2\% 252Bvirus\%252Bin\%252Bwastewaters\%252Band\%252Brivers.\%252BmedRxiv\%252B2020 (accessed on 17 September 2020).

34. Mao, K.; Zhang, K.; Du, W.; Ali, W.; Feng, X.; Zhang, H. The potential of wastewater-based epidemiology as surveillance and early warning of infectious disease outbreaks. Curr. Opin. Environ. Sci. Health 2020, 17, 1-7. [CrossRef]

35. Sodré, F.F.; Brandão, C.; Vizzotto, C.S.; Maldaner, A.O. Wastewater-based epidemiology as a strategy for community monitoring, mapping of hotspots and early warning systems o COVID-19. Química Nova 2020, 43, 515-519.

36. Wu, F.; Xiao, A.; Zhang, J.; Moniz, K.; Endo, N.; Armas, F.; Bonneau, R.; Brown, M.A.; Bushman, M.; Chai, P.R.; et al. SARS-CoV-2 titers in wastewater foreshadow dynamics and clinical presentation of new COVID-19 cases. medRxiv 2020, medRxiv:medrxiv20117747. Available online: https://www.medrxiv.org/search/SARS-CoV-2\%252Btiters\%252Bin\%252Bwastewater\%252Bforeshadow\% 252Bdynamics \%252Band\%252Bclinical\%252Bpresentation\%252Bof\%252Bnew \%252BCOVID-19\%252Bcases (accessed on 17 September 2020).

37. Cascella, M.; Rajnik, M.; Cuomo, A.; Dulebohn, S.C.; Di Napoli, R. Features, evaluation and treatment coronavirus (COVID-19). In StatPearls [Internet]; StatPearls Publishing: Treasure Island, FL, USA, 2020.

38. Borges do Nascimento, I.J.; Cacic, N.; Abdulazeem, H.M.; von Groote, T.C.; Jayarajah, U.; Weerasekara, I.; Esfahani, M.A.; Civile, V.T.; Marusic, A.; Jeroncic, A.; et al. Novel coronavirus infection (COVID-19) in humans: A scoping review and meta-analysis. J. Clin. Med. 2020, 9, 941. [CrossRef] [PubMed]

39. Pant, S.; Singh, M.; Ravichandiran, V.; Murty, U.; Srivastava, H.K. Peptide-like and small-molecule inhibitors against Covid-19. J. Biomol. Struct. Dyn. 2020, 6, 1-10. [CrossRef] [PubMed]

40. Idumah, C.; Zurina, M.; Ogbu, J.; Ndem, J.; Igba, E. A review on innovations in polymeric nanocomposite packaging materials and electrical sensors for food and agriculture. Compos. Interfaces 2019, 27, 1-72. [CrossRef]

41. Joye, I.; Corradini, M.; Duizer, L.; Bohrer, B.; LaPointe, G.; Farber, J.; Spagnuolo, P.A.; Rogers, M.A. A comprehensive perspective of food nanomaterials. Adv. Food Nutr. Res. 2019, 88, 1-45.

42. Chen, C.; Zhang, X.-J.; Wang, Y.; Zhu, L.-X.; Liu, J. Waste water disinfection during SARS epidemic for microbiological and toxicological control. Biomed. Environ. Sci. 2006, 19, 173-178. 
43. Vigneshvar, S.; Sudhakumari, C.; Senthilkumaran, B.; Prakash, H. Recent advances in biosensor technology for potential applications-An overview. Front. Bioeng. Biotechnol. 2016, 4, 11. [CrossRef]

44. Mishra, M.; Singh, S.K.; Shanker, R.; Sundaram, S. Design and simulation of diatom-based microcantilever immunobiosensor for the early detection of Karnal bunt. 3 Biotech. 2020, 10, 1-13. [CrossRef]

45. Tobore, T.O. On the need for the development of a cancer early detection, diagnostic, prognosis, and treatment response system. Future Sci. OA 2019, 6, FSO439. [CrossRef]

46. Miller, C.; Gilmore, J. Detection of quorum-sensing molecules for pathogenic molecules using cell-based and cell-free biosensors. Antibiotics 2020, 9, 259. [CrossRef]

47. Li, Z.; Leustean, L.; Inci, F.; Zheng, M.; Demirci, U.; Wang, S. Plasmonic-based platforms for diagnosis of infectious diseases at the point-of-care. Biotechnol. Adv. 2019, 37, 107440. [CrossRef] [PubMed]

48. Xiao, K.; Liang, S.; Wang, X.; Chen, C.; Huang, X. Current state and challenges of full-scale membrane bioreactor applications: A critical review. Bioresour. Technol. 2019, 271, 473-481. [CrossRef] [PubMed]

49. Obotey Ezugbe, E.; Rathilal., S. Membrane technologies in wastewater treatment: A review. Membranes 2020, 10, 89. [CrossRef]

50. Wang, J.; Shen, J.; Ye, D.; Yan, X.; Zhang, Y.; Yang, W.; Li, X.; Wang, J.; Zhang, L.; Pan, L. Disinfection technology of hospital wastes and wastewater: Suggestions for disinfection strategy during coronavirus Disease 2019 (COVID-19) pandemic in China. Environ. Pollut. 2020, 262, 114665. [CrossRef] [PubMed]

51. Iorhemen, O.T.; Hamza, R.A.; Tay, J.H. Membrane bioreactor (MBR) technology for wastewater treatment and reclamation: Membrane fouling. Membranes 2016, 6, 33. [CrossRef]

52. Liao, Y.; Bokhary, A.; Maleki, E.; Liao, B. A review of membrane fouling and its control in algal-related membrane processes. Bioresour. Technol. 2018, 264, 343-358. [CrossRef]

53. Hubbe, M.A.; Metts, J.R.; Hermosilla, D.; Blanco, M.A.; Yerushalmi, L.; Haghighat, F.; Lindholm-Lehto, P.; Khodaparast, Z.; Kamali, M.; Elliott, A. Wastewater treatment and reclamation: A review of pulp and paper industry practices and opportunities. BioResources 2016, 11, 7953-8091. [CrossRef]

54. Roy, S.; Ragunath, S. Emerging membrane technologies for water and energy sustainability: Future prospects, constraints and challenges. Energies 2018, 11, 2997. [CrossRef]

55. Stoquart, C.; Servais, P.; Bérubé, P.R.; Barbeau, B. Hybrid membrane processes using activated carbon treatment for drinking water: A review. J. Membr. Sci. 2012, 411, 1-12. [CrossRef]

56. Tonkovich, A.; Secker, R.; Reed, E.; Roberts, G.; Cox, J. Membrane reactor/separator: A design for bimolecular reactant addition. Sep. Sci. Technol. 1995, 30, 1609-1624. [CrossRef]

57. Deshpande, A.G. Experimental and Modeling Studies on a Catalytic Packed Bed Membrane Reactor. Ph.D. Thesis, West Virginia University, Morgantown, WV, USA, 1998.

58. Tekere, M. Microbial bioremediation and different bioreactors designs applied. In Biotechnology and Bioengineering; IntechOpen: Rijeka, Croatia, 2019.

59. Juárez-Ramírez, C.; Galíndez-Mayer, J.; Ruiz-Ordaz, N.; Ramos-Monroy, O.; Santoyo-Tepole, F.; Poggi-Varaldo, H. Steady-state inhibition model for the biodegradation of sulfonated amines in a packed bed reactor. New Biotechnol. 2015, 32, 379-386. [CrossRef]

60. Torres-Farradá, G.; Manzano, A.M.; Ramos-Leal, M.; Domínguez, O.; Sánchez, M.I.; Vangronsveld, J.; Guerra, G. Biodegradation and detoxification of dyes and industrial effluents by Ganoderma weberianum B-18 immobilized in a lab-scale packed-bed bioreactor. Bioremediat. J. 2018, 22, 20-27. [CrossRef]

61. Carucci, A.; Manconi, I.; Manigas, L. Use of membrane bioreactors for the bioremediation of chlorinated compounds polluted groundwater. Water Sci. Technol. 2007, 55, 209-216. [CrossRef]

62. Wang, J.; Wu, B.; Sierra, J.M.; He, C.; Hu, Z.; Wang, W. Influence of particle size distribution on anaerobic degradation of phenol and analysis of methanogenic microbial community. Environ. Sci. Pollut. Res. 2020, 27, 10391-10403. [CrossRef] [PubMed]

63. Lesimple, A.; Jasim, S.Y.; Johnson, D.J.; Hilal, N. The role of wastewater treatment plants as tools for SARS-CoV-2 early detection and removal. J. Water Process. Eng. 2020, 38, 101544. [CrossRef]

64. Rakshit, K.; Chatterjee, S.; Bandyopadhyay, D.; Sarkar, S. An effective approach to reduce the penetration potential of Sars-Cov-2 and other viruses by spike protein: Through surface particle electrostatic charge negotiation. arXiv 2020, arXiv:2006.10603.

65. Foladori, P.; Cutrupi, F.; Segata, N.; Manara, S.; Pinto, F.; Malpei, F.; Bruni, L.; La Rosa, G. SARS-CoV-2 from faeces to wastewater treatment: What do we know? A review. Sci. Total Environ. 2020, 743, 140444. [CrossRef] 
66. Vickers, J.C.; Dummer, M.; Le, T.; Zoba, J.B. Removal of MS-2 coliphage in full-scale reverse osmosis systems. AWWA Water Sci. 2019, 1, e1158. [CrossRef]

67. Liu, Q.; Zhou, Y.; Chen, L.; Zheng, X. Application of MBR for hospital wastewater treatment in China. Desalination 2010, 250, 605-608. [CrossRef]

68. Tetteh, E.K.; Obotey Ezugbe, E.; Rathilal, S.; Asante-Sackey, D. Removal of COD and $\mathrm{SO}_{4}{ }^{2-}$ from Oil refinery wastewater using a photo-catalytic system-Comparing $\mathrm{TiO}_{2}$ and zeolite efficiencies. Water 2020, 12, 214. [CrossRef]

69. Tetteh, E.K.; Rathilal, S.; Naidoo, D.B. Photocatalytic degradation of oily waste and phenol from a local South Africa oil refinery wastewater using response methodology. Sci. Rep. 2020, 10, 1-12. [CrossRef] [PubMed]

70. Stackelberg, P.E.; Furlong, E.T.; Meyer, M.T.; Zaugg, S.D.; Henderson, A.K.; Reissman, D.B. Persistence of pharmaceutical compounds and other organic wastewater contaminants in a conventional drinking-water-treatment plant. Sci. Total Environ. 2004, 329, 99-113. [CrossRef]

71. Kim, S.C.; Carlson, K. Quantification of human and veterinary antibiotics in water and sediment using SPE/LC/MS/MS. Anal. Bioanal. Chem. 2007, 387, 1301-1315. [CrossRef] [PubMed]

72. Shu, Z.; Singh, A.; Klamerth, N.; McPhedran, K.; Bolton, J.R.; Belosevic, M.; Gamal El-Din, M. Pilot-scale $\mathrm{UV} / \mathrm{H} 2 \mathrm{O} 2$ advanced oxidation process for municipal reuse water: Assessing micropollutant degradation and estrogenic impacts on goldfish (Carassius auratus L.). Water Res. 2016, 101, 157-166. [CrossRef] [PubMed]

73. Kim, S.C.; Carlson, K. Advanced oxidation processes (AOPs) in wastewater treatment. Curr. Pollut. Rep. 2015, 387, 167-176.

74. Cuerda-Correa, E.M.; Alexandre-Franco, M.F.; Fernández-González, C. Advanced oxidation processes for the removal of antibiotics from water. An overview. Water 2020, 12, 102. [CrossRef]

75. Chollom, M.N.; Rathilal, S.; Swalaha, F.M.; Bakare, B.F.; Tetteh, E.K. Removal of antibiotics during the anaerobic digestion of slaughterhouse wastewater. Planning 2020, 15, 335-343. [CrossRef]

76. Brugnera, M.F.; de Araújo Souza, B.C.; Zanoni, M.V. Advanced oxidation process applied to actinobacterium disinfection actinobacteria. In Basics and Biotechnological Applications; IntechOpen: Rijeka, Croatia, 2016. [CrossRef]

77. Babu, D.S.; Srivastava, V.; Nidheesh, P.V.; Kumar, M.S. Detoxification of water and wastewater by advanced oxidation processes. Sci. Total Environ. 2019, 696, 133961. [CrossRef]

78. Wurtzer, S.; Marechal, V.; Mouchel, J.M.; Moulin, L. Time course quantitative detection of SARS-CoV-2 in Parisian wastewaters correlates with COVID-19 confirmed cases. medRxiv 2020, medRxiv:medrxiv2006267. [CrossRef]

79. Randazzo, W.; Truchado, P.; Cuevas-Ferrando, E.; Simón, P.; Allende, A.; Sánchez, G. SARS-CoV-2 RNA in wastewater anticipated COVID-19 occurrence in a low prevalence area. Water Res. 2020, 16, 115942. [CrossRef]

(C) 2020 by the authors. Licensee MDPI, Basel, Switzerland. This article is an open access article distributed under the terms and conditions of the Creative Commons Attribution (CC BY) license (http://creativecommons.org/licenses/by/4.0/). 